\title{
SOIL FERTILITY: CHALLENGES TO SOYBEAN (Glycine max L.) PRODUCTIVITY IN CONSOLIDATED NO-TILLAGE SYSTEM
}

\author{
Elston Kraft ${ }^{1}$, Luís Carlos Iuñes de Oliveira Filho ${ }^{12}$, Carolina Riviera Duarte Maluche Baretta ${ }^{3}$, \\ Pierre Marcel Perreira ${ }^{4}$, Evandro Spagnollo ${ }^{5}$, Leandro do Prado Wildner ${ }^{5}$, Osmar Klauberg \\ Filho $^{1}$, Dilmar Baretta ${ }^{6}$ \\ ${ }^{1}$ Universidade do Estado de Santa Catarina, Lages, Santa Catarina State, Brazil \\ E-mail: elston@unochapeco.edu.br, osmar.klauberg@udesc.br \\ ${ }^{2}$ Universidade Federal de Pelotas, Capão do Leão, Rio Grande do Sul State, Brazil \\ E-mail: iunes1981@gmail.com \\ ${ }^{3}$ Universidade Comunitária da Região de Chapecó, Chapecó, Santa Catarina State, Brazil \\ E-mail: carolmaluche@ unochapeco.edu.br \\ ${ }^{4}$ Universidade Federal de Santa Catarina, Florianópolis, Santa Catarina State, Brazil \\ E-mail: pierre_marcel@outlook.com \\ ${ }^{5}$ Empresa de Pesquisa Agropecuária e Extensão Rural de Santa Catarina, Chapecó, Santa Catarina State, Brazil \\ E-mail: spagnollo@epagri.sc.gov.br, lpwild@epagri.sc.gov.br \\ ${ }^{6}$ Universidade do Estado de Santa Catarina, Chapecó, Santa Catarina State, Brazil \\ E-mail: dilmar.baretta@udesc.br
}

\begin{abstract}
The objective was to evaluate the relationship of soil fertility in areas with productivities gradients of soybean managed under no-tillage system (NT) in Western Santa Catarina, Brazil, and the interaction of this fertility with the physical and biological attributes of the soil. Areas with NT of High (NTH), Medium (NTM) and Low (NTL) soybean productivity were selected during the agricultural years 2016/2017 and 2017/2018. In each system, a sampling grid of $3 \times 3$ points, positioned $30 \mathrm{~m}$ apart, was used. Univariate analysis of the data showed no difference between the systems. However, principal component analysis helped identify the attributes that can affect productivity. Redundancy analysis identified the influence of biological attributes on some soil nutrients. The explanation for higher soybean productivities in NT system should not consider just the chemical fertility of the soil, but a holistic approach to fertility.
\end{abstract}

Keywords: Nutrient availability, conservation agriculture, soil biology 


\section{FERTILIDADE DO SOLO: DESAFIOS À PRODUTIVIDADE DE SOJA (Glicine max L.) EM SISTEMA PLANTIO DIRETO CONSOLIDADO}

\section{RESUMO}

Objetivou-se avaliar a relação da fertilidade do solo em áreas com gradientes de produtividade de soja manejadas sob SPD no Oeste Catarinense, e, a interação desta fertilidade com os atributos físicos e biológicos do solo. Foram selecionadas áreas com SPD de Alta (SPDA), Média (SPDM) e Baixa (SPDB) produtividade de soja durante os anos agrícolas 2016/2017 e 2017/2018. Em cada sistema, utilizou-se uma grade amostral de $3 \times 3$ pontos, a uma distância de $30 \mathrm{~m}$ entre pontos. A análise univariada dos dados não mostrou diferença entre os sistemas. No entanto, a análise de componentes principais auxiliou na identificação dos atributos que contribuíram com as diferentes produtividades. A análise de redundância identificou a influência de atributos biológicos sobre alguns nutrientes do solo. A explicação para maiores produtividades de soja em SPD não devem levar em conta apenas a condição química do solo e, sim, uma abordagem holística da fertilidade.

Palavras-chave: Disponibilidade de nutrientes, agricultura conservacionista, biologia do solo

\section{INTRODUCTION}

The concept of fertility refers to the soil's ability to supply nutrients that are essential for plant development, in appropriate quantities and proportions, and absence of toxic elements to improve the productivity of crops (LOPES \& GUILHERME, 2007; NICOLODI et al., 2014). According to Liebig's law of the minimum (Justus von Liebig, 1840), the response of a plant is limited by the nutrient that is in smaller quantity in the soil, according to the need of the crop. This concept is so valid that, since then, it has been applied and disseminated worldwide.

From the agronomic point of view, before planting a crop, it is necessary to perform sampling and chemical analysis of the soil, followed by interpretation of the results, recommendation of fertilization (chemical and/or organic fertilizers) and liming, when necessary. This procedure aims to increase/maintain soil fertility to promote gains in crop productivity (NICOLODI et al., 2014). Nutrient availability can be influenced by forms of application, type of soil, and soil management system. Proof of this is that areas managed under no-tillage (NT), in the long term, show an increase in organic matter, which promotes changes in microbial stability and 
diversity (WANG et al., 2017) and, consequently, in the availability of nutrients (MOREIRA et al., 2016).

The NT was implemented in the early 70s, showing a great expansion from the 90s (MOTTER et al., 2015), and in the 2017/2018 season there were more than 32 million hectares cultivated in Brazil (FEBRAPDP, 2020). It stands out as an effective strategy to improve the sustainability of agriculture and reduce the problems caused by erosion through the use of crop rotation, soil turning only in the cultivation row, and permanent cover (CAIRES et al., 2011; RODRIGHERO et al., 2015). This change in the cultivation system with the transition from intensive management such as conventional planting to a more conservational system, such as NT, brings undeniable benefits (FAVARATO et al., 2015; TIECHER et al., 2017) and draws attention to the application of the mineralist concept of soil fertility (NICOLODI et al., 2014).

The mineralist concept deals with the magnitude of soil fertility perceived by plants, given solely by the supply and presence of nutrients in the soil via fertilizer (NICOLODI \& GIANELLO, 2015). This concept needs to be reviewed in soils cultivated under NT since the nutrient $x$ productivity relationship alone cannot explain the production shown by the crops in this system (NICOLODI et al., 2014).

It is known that the NT promotes nutrient accumulation in the soil surface layer $(0-10 \mathrm{~cm})$ (TIECHER et al., 2017), due to higher concentration of roots and material deposition on the soil surface. However, the NT also promotes circumstantial changes in physical attributes (BLANCOCANQUI \& RUIS, 2018; PEREIRA et al., 2018) and mainly in soil biological attributes (BARETTA et al., 2014; BEDANO et al., 2016). Thus, the interaction between these attributes can contribute to the change in nutrient availability, or even to how plants perceive fertility in the first centimeters of soil and throughout the area explored by the roots. This is due to the so-called rhizospheric effect, since the existing interrelationships between chemical, physical and biological attributes control the processes and aspects related to the variation of time and space, with effects on soil quality and agricultural productivity (CARVALHO et al., 2018).

Thus, for a better understanding of these interactions (chemical, physical and biological) as well as the use of a broad dataset, it is necessary to use multivariate data analysis tools (BELINATO et al., 2020). The use of multivariate analysis techniques is more efficient to explore the correlations between the variables and determine those that most contribute to soil characterization and changes (CARVALHO et al., 2018). 
In view of the above, the hypotheses are: I) In consolidated NTS, high levels of fertility do not guarantee high soybean productivity; and II) Using the multivariate analysis technique can help understand the chemical attributes in NT with different soybean yields and the physical and biological factors that affect them. Therefore, the objective of this study was to evaluate the relationship of soil fertility in areas with productivity gradients of soybean (Glycine max L.) managed under NT in Western Santa Catarina, as well as the interaction of this fertility with the physical and biological attributes of the soil.

\section{MATERIAL AND METHODS}

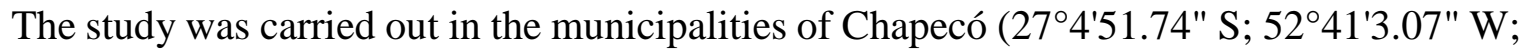

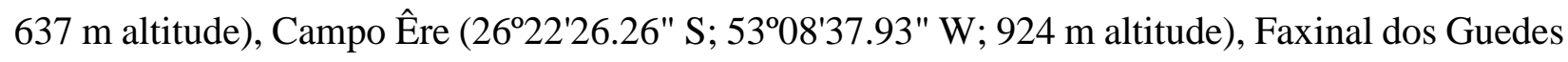
(264'14.36" S; 52¹4'56.23" W; 859 m altitude), and Maravilha (26⒋'2.11" S; 536'54.13" W; $623 \mathrm{~m}$ altitude) located in the Western Region of Santa Catarina State, Brazil, during the agricultural years 2016/2017 and 2017/2018, except for Maravilha, where the study was conducted only in the agricultural year 2017/2018. The sampled sites are characterized by the use of the notillage system (NT) with more than sixteen years of implementation. In each municipality (true replicate), areas with the same history of crop management were selected to avoid interference in the analyses (Table 1).

NT areas were selected in each municipality with different levels/gradients of soybean (Glycine max L.) productivity: Low (NTL, $<2,400 \mathrm{~kg} \mathrm{ha}^{-1}$ ), Medium (NTM, between 3,600 and 2,400 $\left.\mathrm{kg} \mathrm{ha}^{-1}\right)$, and High (NTH > 3,600 $\mathrm{kg} \mathrm{ha}^{-1}$ ). The areas were selected considering the average yield of the Santa Catarina state in the 2015/2016 season, according to the Companhia Nacional de Abastecimento $\left(3,341 \mathrm{~kg} \mathrm{ha}^{-1}\right)$ and the knowledge of researchers and agronomists linked to the rural extension who know the region. In the years evaluated, the average soybean yield ranged from $1,711 \mathrm{~kg} \mathrm{ha}^{-1}$ in NTL areas to $8,101 \mathrm{~kg} \mathrm{ha}^{-1}$ in NTH areas. Field collections were performed using a sampling grid of $3 \times 3$ points, in which the sampling points were $30 \mathrm{~m}$ away from each other and $20 \mathrm{~m}$ away from the border, in a total area of 1 hectare (ha) for each of the productivity levels (NTH, NTM, and NTL), totaling 189 points sampled during the two agriculture years of evaluation (Figure 1). Soil samples were collected at the beginning of the soybean reproductive stage (phenological stage - R2), which coincides with December and January, depending on the period of implementation in each municipality and on the cycle of the cultivar used by each farmer. 
Table 1. Characterization of collection sites managed under no-tillage system of High (NTH), Medium (NTM), and Low (NTL) soybean productivity.

\begin{tabular}{|c|c|c|c|c|c|c|}
\hline \multirow{2}{*}{ Cities } & \multirow{2}{*}{ Treatments } & \multicolumn{3}{|c|}{ Fertilization $\left(\mathrm{kg} \mathrm{ha}^{-1}\right)$} & \multirow{2}{*}{$\begin{array}{l}\text { Years under } \\
\text { NTS }\end{array}$} & \multirow{2}{*}{ Agrochemicals } \\
\hline & & $\mathrm{N}^{1}$ & $\mathrm{P}^{1}$ & $\mathrm{~K}^{1}$ & & \\
\hline \multicolumn{7}{|c|}{ Agricultural Year 2016/2017 } \\
\hline \multirow{4}{*}{ Campo Êre } & NTH & \multirow{4}{*}{12} & \multirow{4}{*}{84} & \multirow{4}{*}{84} & 20 & \multirow{4}{*}{$\begin{array}{ll}\text { Ammonium glyphosate } & \text { salt; Trifloxystrobin }+ \\
\text { Cyproconazole; } & \text { Azoxystrobin } \\
\text { Benzovindiflupyr; } & \text { Trifloxystrobin } \\
\text { Prothioconazole. } & \end{array}$} \\
\hline & & & & & & \\
\hline & NTM & & & & 20 & \\
\hline & NTL & & & & 20 & \\
\hline \multirow{3}{*}{ Chapecó } & NTH & \multirow{3}{*}{5} & \multirow{3}{*}{50} & \multirow{3}{*}{50} & 18 & \multirow{3}{*}{$\begin{array}{ll}\text { Ammonium glyphosate salt; Trifloxystrobin }+ \\
\text { Cyproconazole; } & \text { Azoxystrobin } \\
\text { Benzovindiflupyr. } & \end{array}$} \\
\hline & NTM & & & & 18 & \\
\hline & NTL & & & & 18 & \\
\hline \multirow{4}{*}{$\begin{array}{l}\text { Faxinal dos } \\
\text { Guedes }\end{array}$} & NTH & \multirow{4}{*}{0} & \multirow{4}{*}{47.6} & \multirow{4}{*}{87.2} & 33 & \multirow{4}{*}{$\begin{array}{l}\text { Potassium glyphosate; } \\
\text { Lambda-Cyhalothrin; } \\
\text { Azoxystrobin + Benzovindiflupyr; Imidacloprid } \\
\text { + Bifenthrin; Mancozeb; Fluxapyroxad + } \\
\text { Pyraclostrobin; Bifenthrin. }\end{array}$} \\
\hline & & & & & & \\
\hline & NIIVI & & & & 24 & \\
\hline & NTL & & & & 33 & \\
\hline \multirow{4}{*}{ Maravilha } & NTH & \multirow{4}{*}{15} & \multirow{4}{*}{67.5} & \multirow{4}{*}{105} & 28 & \multirow{4}{*}{$\begin{array}{l}\text { Ammonium glyphosate salt; Trifloxystrobin + } \\
\text { Prothioconazole; Methoxyfenozide; } \\
\text { Chlorantraniliprole; Mancozeb; Azoxystrobin + } \\
\text { Benzovindiflupyr; Imidacloprid; Chlorfenapyr; } \\
\text { Flubendiamide. }\end{array}$} \\
\hline & & & & & & \\
\hline & NTM & & & & 28 & \\
\hline & NTL & & & & 16 & \\
\hline
\end{tabular}

Agricultural Year 2017/2018

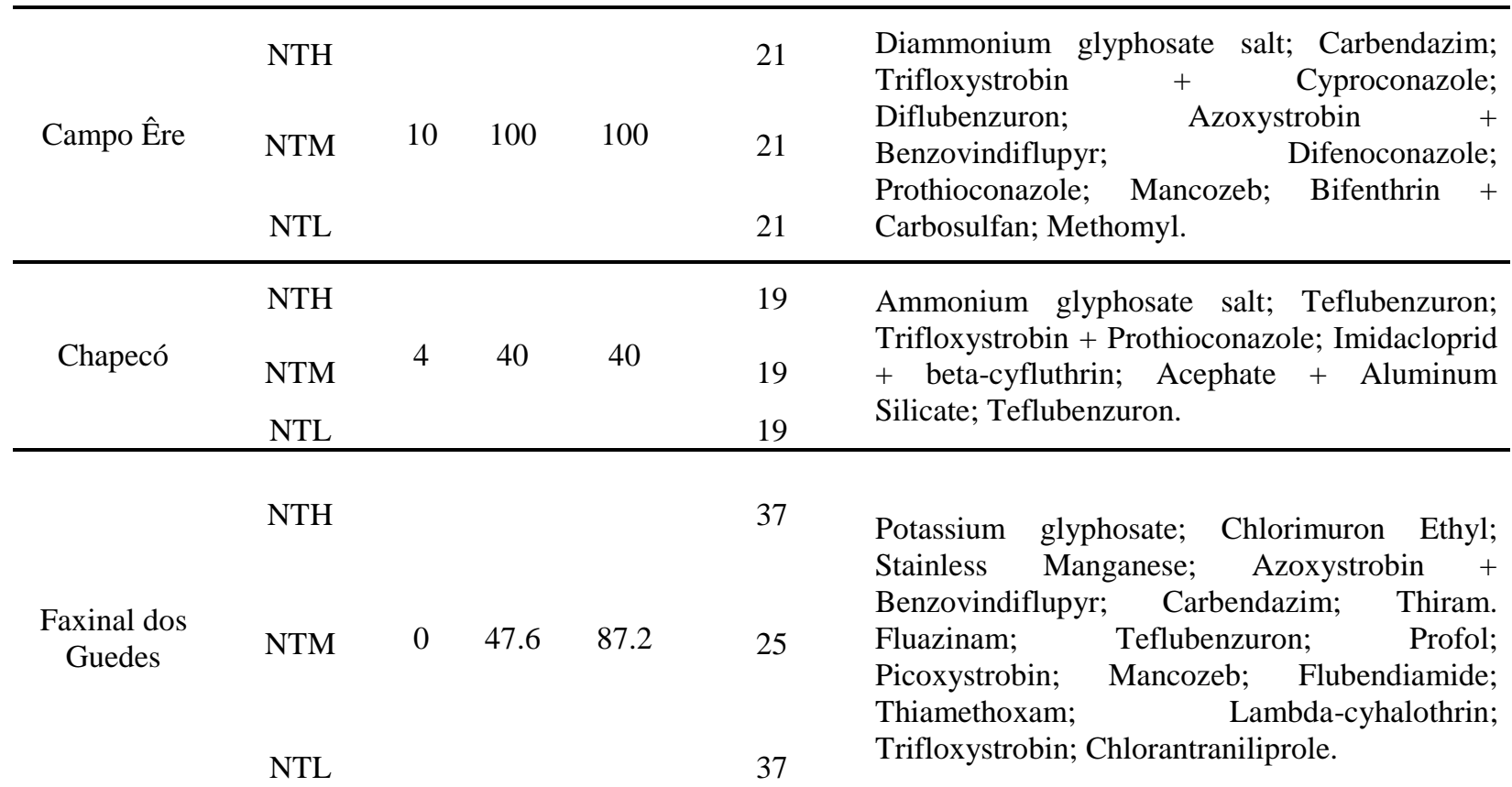

Adapted from Kraft et al., 2021. 


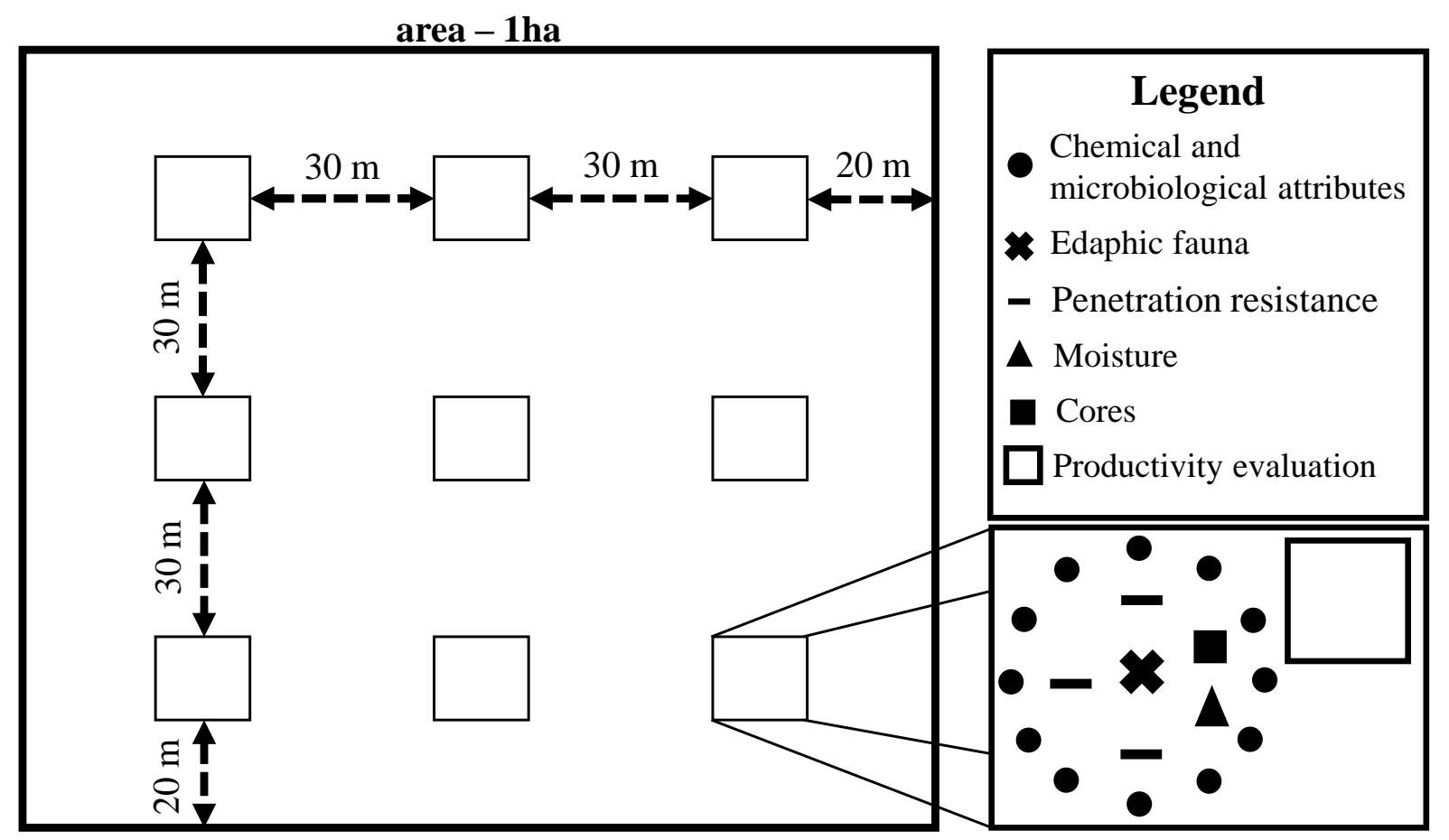

Figure 1. Schematic representation of soil sample collection and determinations performed in areas managed under no-tillage system of High (NTH), Medium (NTM), and Low (NTL) soybean productivity, located in the municipalities of Maravilha, Campo Êre, Chapecó, and Faxinal dos Guedes, Santa Catarina State, Brazil, in the 2016/17 and 2017/18 seasons.

Soil sampling for chemical evaluations was performed around a central collection point, using a Dutch auger; each main sample consisted of 12 subsamples collected in the $0.00-0.10 \mathrm{~m}$ layer. After collection, the samples were sent for analysis in the soil laboratory of EPAGRI/CEPAF/CHAPECÓ, to determine the levels of Phosphorus (P), Potassium (K), Organic Matter (OM), Calcium (Ca), Magnesium (Mg), Cation Exchange Capacity $\left(\mathrm{CEC}_{\mathrm{pH} 7.0}\right)$, Base Saturation (V\%), Aluminum Saturation $(\mathrm{m} \%)$ and $\mathrm{pH}$-water, according to the methodology of Tedesco (1995) (standard methodology adopted by the Official Network of Laboratories of Soil and Plant Tissue Analysis of the Rio Grande do Sul State and Santa Catarina State).

Among the biological variables, considered explanatory variables, the edaphic fauna sampled by soil monoliths with dimensions of $25 \times 25 \mathrm{~cm}$ and $10 \mathrm{~cm}$ depth (ANDERSON \& INGRAM, 1993) was evaluated. For its screening, macrofauna organisms were manually captured with the aid of artificial lighting. All organisms found were kept in $70 \%$ alcohol, except for earthworms, which were kept in $92.8 \%$ alcohol. Subsequently, the organisms of the edaphic fauna 
were identified at the taxonomic level of Class/Subclass/Order/Epifamily (RUGGIERO et al., 2015), using a stereoscopic microscope (40x magnification), quantified and deposited in absolute alcohol. At the same points where chemical sampling was carried out, samples were collected to evaluate microbial biomass carbon (MBC), by the fumigation-extraction method (VANCE et al., 1987), and microbial activity, determined by soil basal respiration (SBR) (ALEF and NANNIPIERI, 1995). The results of SBR and MBC were used to calculate the metabolic quotient $\left(q \mathrm{CO}_{2}\right)$ as proposed by Anderson and Domsch (1993), and the total organic carbon (TOC) and MBC values were used to calculate the microbial quotient ( $q \mathrm{Mic}$ ).

As physical variables, penetration resistance (PR) and soil moisture (Uv) were determined at the time of field sampling, using a digital penetrometer and an electronic soil moisture meter based on frequency domain reflectometry (FDR), respectively. Other soil physical evaluations were performed in the laboratory from samples collected in volumetric rings at each point evaluated. The rings with soil were saturated in trays and placed on a tension table and subjected to tensions of $10 \mathrm{kPa}, 60 \mathrm{kPa}$, and $100 \mathrm{kPa}$, to determine the microporosity (mic); bioporosity (bio), and macroporosity (macro). Soil bulk density (BD) was obtained by dividing dry soil mass by the ring volume. The physical variables were determined following the methodologies proposed by EMBRAPA (1997).

Soybean yield was evaluated when the plants were at field maturity (Stage R8) by collecting $1 \mathrm{~m}^{2}$ at each collection point (Figure 1).

For data analysis, the points within each municipality were reordered to better separate the most productive points from the least productive ones, which was only possible because the data collections were made for each point sampled, respecting a distance $(30 \mathrm{~m})$ that guarantees the independence of the points. From these points, the treatments were grouped (NTH, NTM, and NTL) and the mean was calculated, considering each municipality a true replicate of the evaluated system, according to Kraft et al. (2021). Thus, three levels of productivity $\times$ four municipalities (3 $\times 4=12$ ) were established in the 2016/2017 agricultural year and three levels of productivity $\times$ three municipalities $(3 \times 3=9)$ were established in the 2017/2018 agricultural year.

The data were subjected to the Shapiro-Wilk normality and Bartlett homogeneity tests, and the means were compared by the LSD test $(p<0.05)$ between the NTs. When necessary, the data were transformed by Box-Cox. Linear regressions were performed between soybean productivities in the NTs and chemical attributes found to demonstrate the relationship between variables and 
productivity. In order to better understand the relationship between soil chemical attributes and productivity levels, principal component analysis (PCA) was performed. Collinear explanatory variables were identified through Variance Inflation Factor (VIF) and Forward Selection operations, using successive Redundancy Analyses (RDA) based on permutations by the MonteCarlo test for each type of variable, removing those that showed collinearity and maintaining the significant ones $(p<0.05)$. Characteristics such as altitude, longitude, and latitude of each sampling site were used as covariates in the analysis.

\section{RESULTS AND DISCUSSION}

The evaluation of soil chemical attributes focusing on nutrient availability can be performed by an agronomic or statistical approach (TIECHER et al., 2017); the most common is through the statistical difference in the values found, regardless of agronomic relevance (RHEINHEIMER et al., 2018). However, in this study, initially it was decided to use an agronomic approach in the interpretation and discussion of the data; later, based on statistical tools, an attempt was made to understand the contributions of chemical attributes in NT and their interactions with physical and biological attributes.

The critical limits for plant growth and productivity were defined using the official recommendation of the Soil Chemistry and Fertility Commission for the Rio Grande do Sul and Santa Catarina states (CQFS - RS/SC, 2016). The values found for the chemical attributes did not show differences between productivity levels and the chemical variables analyzed $(p>0.05)$ (Table 2). However, all nutrients in all systems showed values above the critical level; for $\mathrm{pH}$ and base saturation $(\mathrm{V} \%)$ they were above the minimum value referenced for NT, and low aluminum saturation ( $\mathrm{m} \%$ ), according to CQFS - RS/SC (2016) for crops of group 2 (grains) under conditions of no-tillage system.

Figure 2 shows that there was no correlation between $\mathrm{P}, \mathrm{K}, \mathrm{Ca}$, and $\mathrm{Mg}$ levels and soybean productivity $\left(\mathrm{kg} \mathrm{ha}^{-1}\right)$. According to CQFS - RS/SC (2016), it is known that the productive response of crops to fertilization decreases from the critical level. However, $\mathrm{P}, \mathrm{K}, \mathrm{Ca}$, and $\mathrm{Mg}$ values well above the critical level also generated a decrease in soybean productivity, so the first hypothesis is accepted. The critical level in these studies is defined as the concentration of the nutrient in the soil that corresponds to the availability necessary to achieve the production of maximum economic efficiency (ALVAREZ, 1996), which corresponds to $90 \%$ of the maximum productive response (SCHERER, 1998). 
Table 2. Evaluation of chemical attributes in the no-tillage systems of High (NTH), Medium (NTM), and Low (NTL) soybean productivity in Western Santa Catarina State, Brazil. $\mathrm{n}=21$

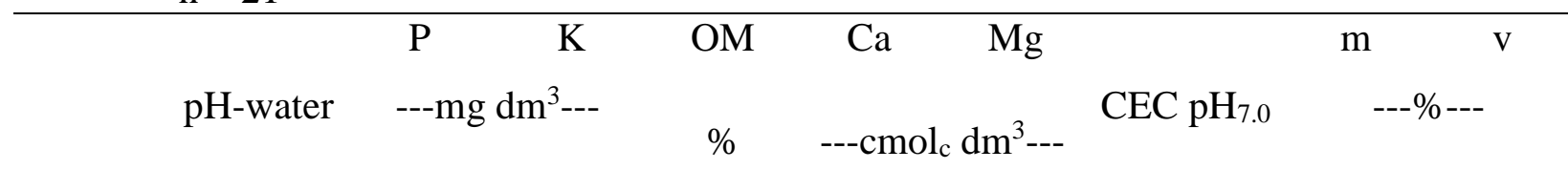

\begin{tabular}{lrrrrrrrrr}
\hline NTH & $5.59^{\text {ns }}$ & $16.84^{\text {ns }}$ & $229.49^{\text {ns }}$ & $4.32^{\text {ns }}$ & $6.87^{\text {ns }}$ & $2.63^{\text {ns }}$ & $14.90^{\text {ns }}$ & $3.37^{\text {ns }}$ & $67.56^{\text {ns }}$ \\
NTM & 5.67 & 15.36 & 212.11 & 4.27 & 7.21 & 2.92 & 15.44 & 3.39 & 69.25 \\
NTL & 5.71 & 15.49 & 229.03 & 4.27 & 6.97 & 2.92 & 14.99 & 3.59 & 69.52 \\
\hline C.V.(\%) & 6.13 & 48.46 & 26.13 & 22.71 & 15.92 & 36.14 & 10.86 & 154.98 & 10.56
\end{tabular}

Means compared by LSD test $(p<0.05)$.

${ }^{n s}$ Not significant.
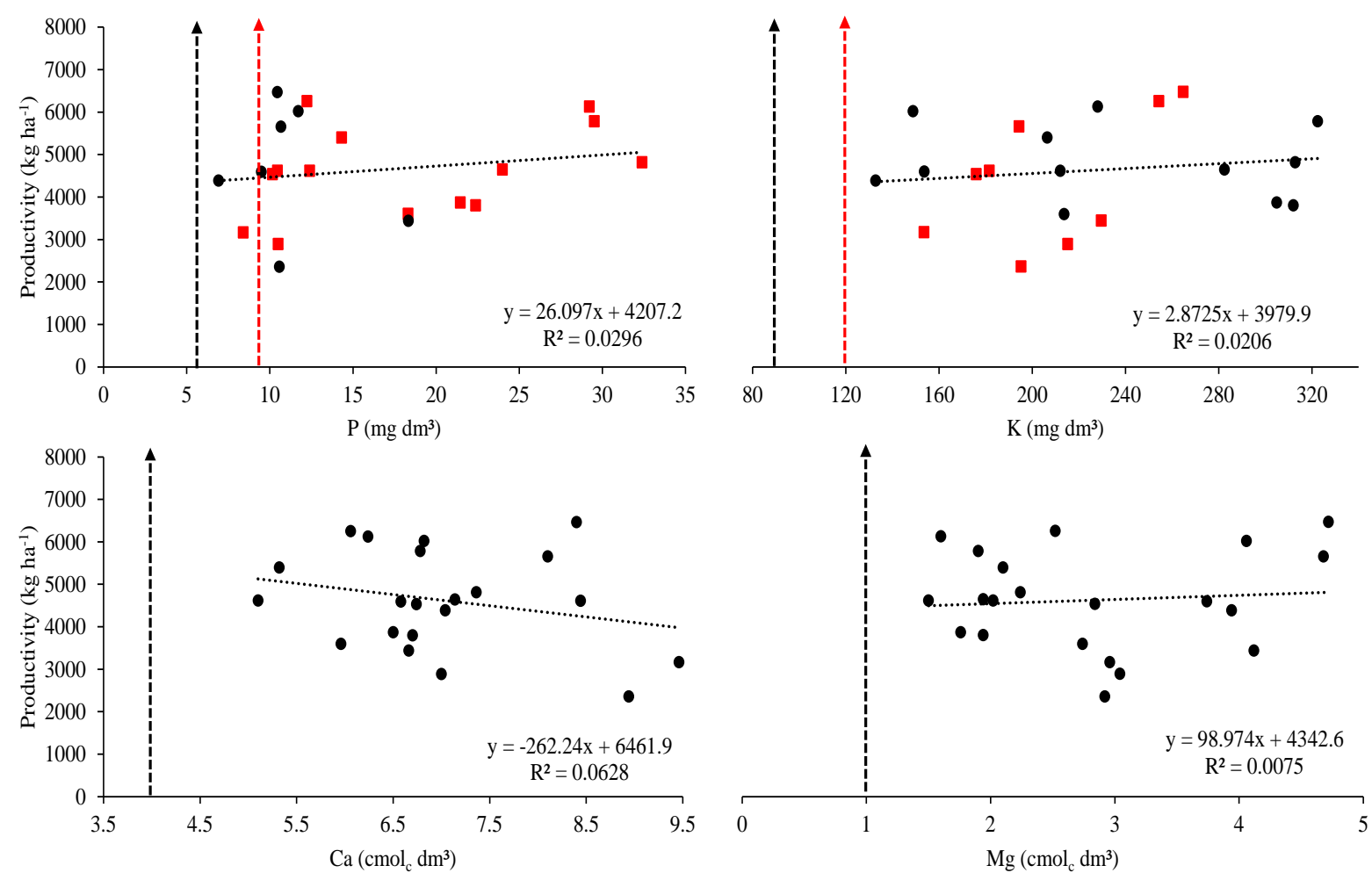

Figure 2. Regression between levels of phosphorus $(\mathrm{P})$, potassium $(\mathrm{K})$, calcium $(\mathrm{Ca})$, magnesium $(\mathrm{Mg})$, and soybean productivity $\left(\mathrm{kg} \mathrm{ha}^{-1}\right)$ in soils managed under no-tillage system (NTS) in Western Santa Catarina State, Brazil $(n=21)$. Vertical dashed lines represent respectively the critical level for grain crop, being for class 2 (black) and 3 (red) of clay in the availability of $\mathrm{P}, \mathrm{CEC}_{\mathrm{ph} 7.0}, 7.6$ to 15 (black), and 15.1 to 30 (red) for the availability of $\mathrm{K}$ and (black) for $\mathrm{Ca}$ and $\mathrm{Mg}$ according to CQFS - RS/SC, 2016. 
The concentrations of organic $\mathrm{P}$ in the soil can constitute 5 to $80 \%$ of the total $\mathrm{P}$, and it needs to be taken into account in studies on bioavailability to plants (RHEINHEIMER \& ANGHINONI, 2003). This fraction of $\mathrm{P}$ is the result of the decomposition of plant residues and microbial tissue (and the products resulting from decomposition) (MARTINAZZO et al., 2007), which tend to increase in soils managed in conservation systems such as NTS. However, according to Santos et al. (2008), due to the wide variety of organic compounds present in the soil, more than half of the organic forms of $\mathrm{P}$ are still unknown. Therefore, it becomes less understandable to what extent the P values found in soil analysis affect soybean productivity in NT, since this system maintains soil cover, favoring biological diversity and activity as well as the accumulation of organic matter in the soil. The increase in soil organic matter content affects the sorption of nutrients such as $\mathrm{P}$, so there is the formation of complexes with humic substances, even reducing the leaching of the nutrient (DEBICKA et al., 2016).

The data found by Vieira et al. (2015) demonstrated that soils with lower P availability under NT promote higher coefficients of determination $\left(\mathrm{R}^{2}\right)$ of the fitted equation between grain productivity and $\mathrm{P}$ doses. However, soil $\mathrm{P}$ contents ranged from 1.2 to $18.6 \mathrm{mg} \mathrm{dm}^{-3}$. It must be highlighted that in a study conducted previously, in the same region, evidence was recorded that the $0-20 \mathrm{~cm}$ layer has a higher relationship with crop productivity and with other nutritional parameters than the 0-10 $\mathrm{cm}$ layer in soils with a long history (in this study with more than 30 years) of NT adoption (VIEIRA, 2010). Studies consider NT with more than five years as consolidated (NOLLA \& ANGHINONI, 2006), and NT with more than 14 years of implementation as long-term (REICHERT et al., 2016); therefore, regarding the evaluated areas, all have more than 16 years of NT implementation and some reach 37 years. Thus, it should be considered that the evaluation of fertility in the $0-10 \mathrm{~cm}$ layer over a long period of NT alone may be insufficient for an adequate understanding between soil fertility and soybean productivity.

The $\mathrm{K}^{+}$contents found in this study were above the critical limits for both classes of

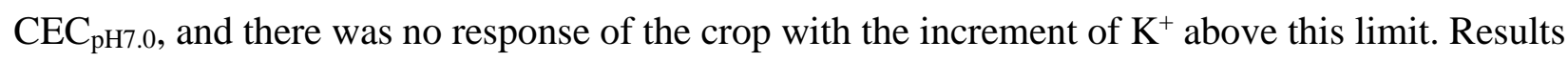
found by Fernández et al. (2009) tested the production response of soybean in NTS under low, medium, and high $\mathrm{K}$ availability, and observed only increased nutrient absorption by the plant with no increment in productivity (luxury consumption) from the critical level.

Although $\mathrm{Ca}^{2+}$ levels are above the critical limit (Figure 2), no relationship was observed between nutrient availability and soybean productivity. Caires et al. (2011), evaluating the 
application of limestone and agricultural gypsum in different forms in NT, found no relationship between $\mathrm{Ca}^{2+}$ content and soybean productivity. However, the authors highlighted a positive correlation of the nutrient at greater soil depths for the corn crop.

This lack of response of soybeans to the high concentrations of $\mathrm{Ca}^{2+}$ and $\mathrm{Mg}^{2+}$ may be due to the high cation exchange capacity of legume roots (ASHER \& OZANNE, 1961), being even twice that of grasses (FERNANDES \& SOUZA, 2006). This characteristic can enable soybeans, for example, to meet their nutritional needs for $\mathrm{Ca}^{2+}$ and $\mathrm{Mg}^{2+}$ even below the reference levels.

Figure 3 also shows the lack of significant correlation of $\mathrm{V} \%, \mathrm{~m} \%, \mathrm{OM}$, and $\mathrm{pH}$ in water with soybean productivity $\left(\mathrm{kg} \mathrm{ha}^{-1}\right)$. It is worth pointing out that, even with points below the reference value, high productivities are found and the opposite is also true.
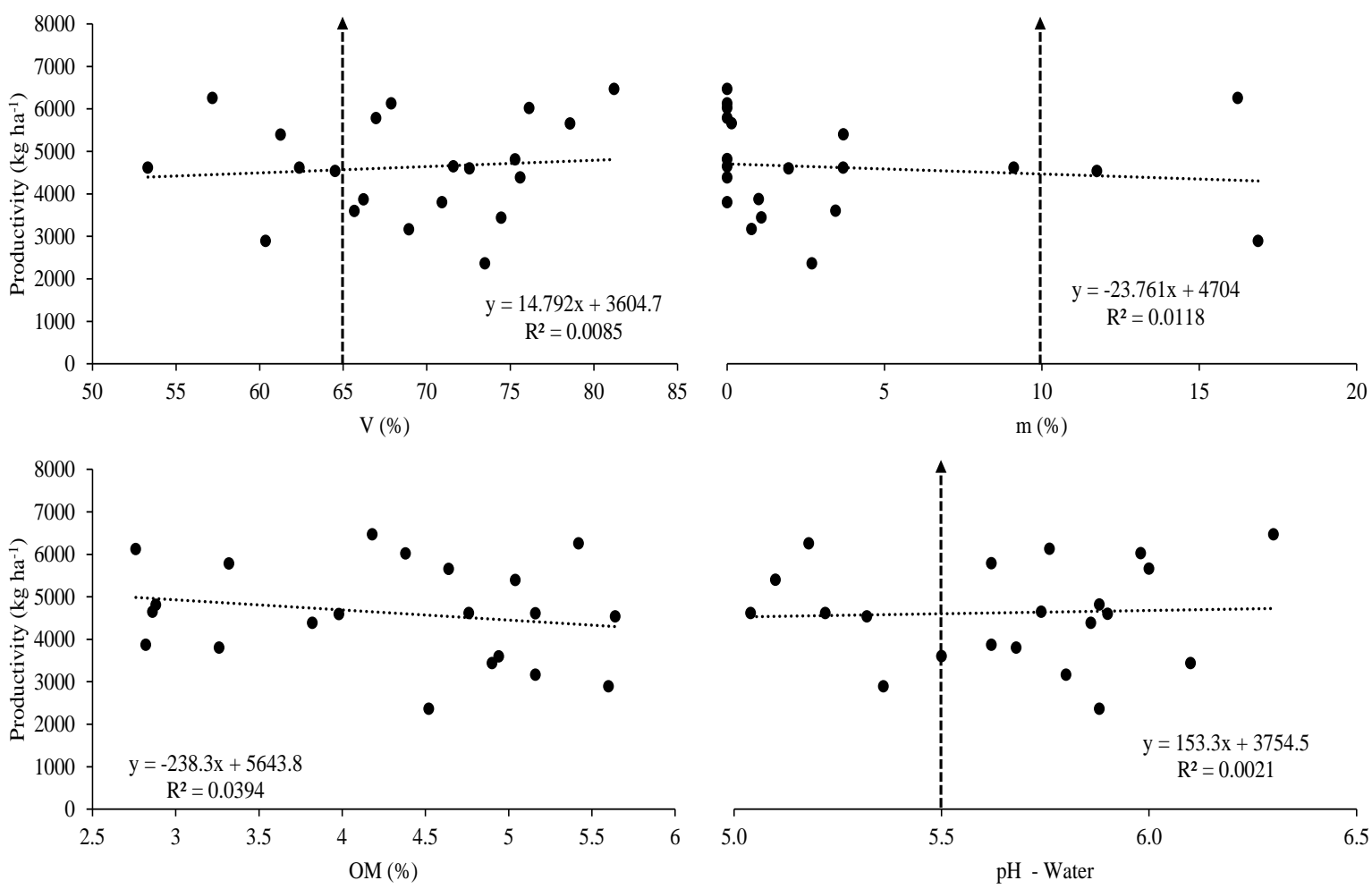

Figure 3. Regression between base saturation [V (\%)], aluminum saturation [m (\%)], Organic Matter [OM (\%)], and $\mathrm{pH}$ in water and soybean productivity $\left(\mathrm{kg} \mathrm{ha}^{-1}\right)$ in soils managed under no-tillage system (NTS) in Western Santa Catarina State, Brazil $(\mathrm{n}=21)$. Vertical dashed lines represent reference values according to CQFS - RS/SC, 2016.

Soil acidity hampers the availability of $\mathrm{N}, \mathrm{P}, \mathrm{K}, \mathrm{Mg}, \mathrm{S}$, and $\mathrm{OM}$ for plants, and may cause toxicity by $\mathrm{Mn}^{2+}$ and $\mathrm{Al}^{3+}$ (RODRIGHERO et al., 2015). In addition, acidic soils commonly also have $\mathrm{Ca}$ deficiency, whose conditions can cause impediments to root penetration (FAGERIA, 
2001). Nevertheless, it is noted that even under conditions of high aluminum saturation (> 10\%) and low $\mathrm{pH}(<5.5)$ there are high soybean productivities, which probably occurred due to the high average levels of OM (Table 2), which complexes toxic elements such as $\mathrm{Al}^{+3}$ through organic acids (mainly humic and fulvic acids), inhibiting even the adsorption of nutrients such as $\mathrm{P}$ (PAVINATO \& ROSOLEM, 2008). Other authors have reported high production of soybean and corn grains in acidic soils managed under NT (CAIRES et al., 2005; 2006). The same occurs for base saturation (V\%), which corresponds to the percentage of basic cations such as $\mathrm{Ca}^{2+}, \mathrm{Mg}^{2+}, \mathrm{K}^{+}$,

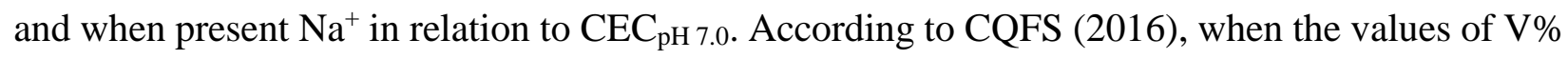
in NT are above $65 \%$ there is no need to apply limestone, that is, there would be no restrictions on plant development and productivity; however, there are points with high productivity even with the saturation below this value.

Soil OM contents varied widely, with values close to that considered low $(<2.5 \%)$ up to high values $(>5 \%)$. The lack of response between OM percentage and soybean productivity in NT has already been reported by Nicolodi and Gianelo (2017). The authors emphasize that the use of $\mathrm{OM}$ is insufficient as an indicator of the improvement of fertility and the relationship with productivity. They highlight that the results obtained by several researchers suggest the need for biological and physical indicators to express soil fertility, especially those related to the decomposition and transformation of organic matter. In this context, the results draw attention to not only the use of quantitative metrics but also the need for qualitative analysis of OM in NT.

The use of multivariate analysis considers a set of response and explanatory variables, being a useful tool to the limitations found in univariate analyses. The Principal Component Analysis (PCA) showed a satisfactory explanation of the data, differentiating the NTH, NTM, and NTL soybean productivity systems, confirming the second hypothesis. The principal component 1 (PC1) explained $46.7 \%$ of the data and principal component 2 (PC2) explained $29.8 \%$ of the data, representing $75.6 \%$ of the total variability of the data (Figure 4).

PC1 demonstrates a clear separation of the NTH and NTM systems from NTL, favored by OM. Practices such as NT are recognized in the maintenance or elevation of soil OM levels (MANGALASSERY et al., 2015; MOREIRA et al., 2016), as well as the knowledge of the benefits that OM has on the physical attributes, availability of nutrients (MURPHY, 2015) and mainly on diversity and biological functions (MANGALASSERY et al., 2015); the result of this set is crop productivity. The analysis demonstrated a relationship of NTL with the highest $\mathrm{pH}$ values in water, 
while for NTM there was a relationship with cation exchange capacity $\left(\mathrm{CEC}_{\mathrm{pH} 7.0}\right)$. In $\mathrm{NTH}$, a relationship was observed with the levels of $\mathrm{Al}^{3+}$, although most of the sampled systems showed saturation below the harmful limit (10\%) (CQFS - RS/SC, 2016). Therefore, it can be inferred that, in situations where nutrients are above the critical level (Figure 2), the presence of $\mathrm{Al}^{3+}$ did not affect the high productivities of soybean in NTs.

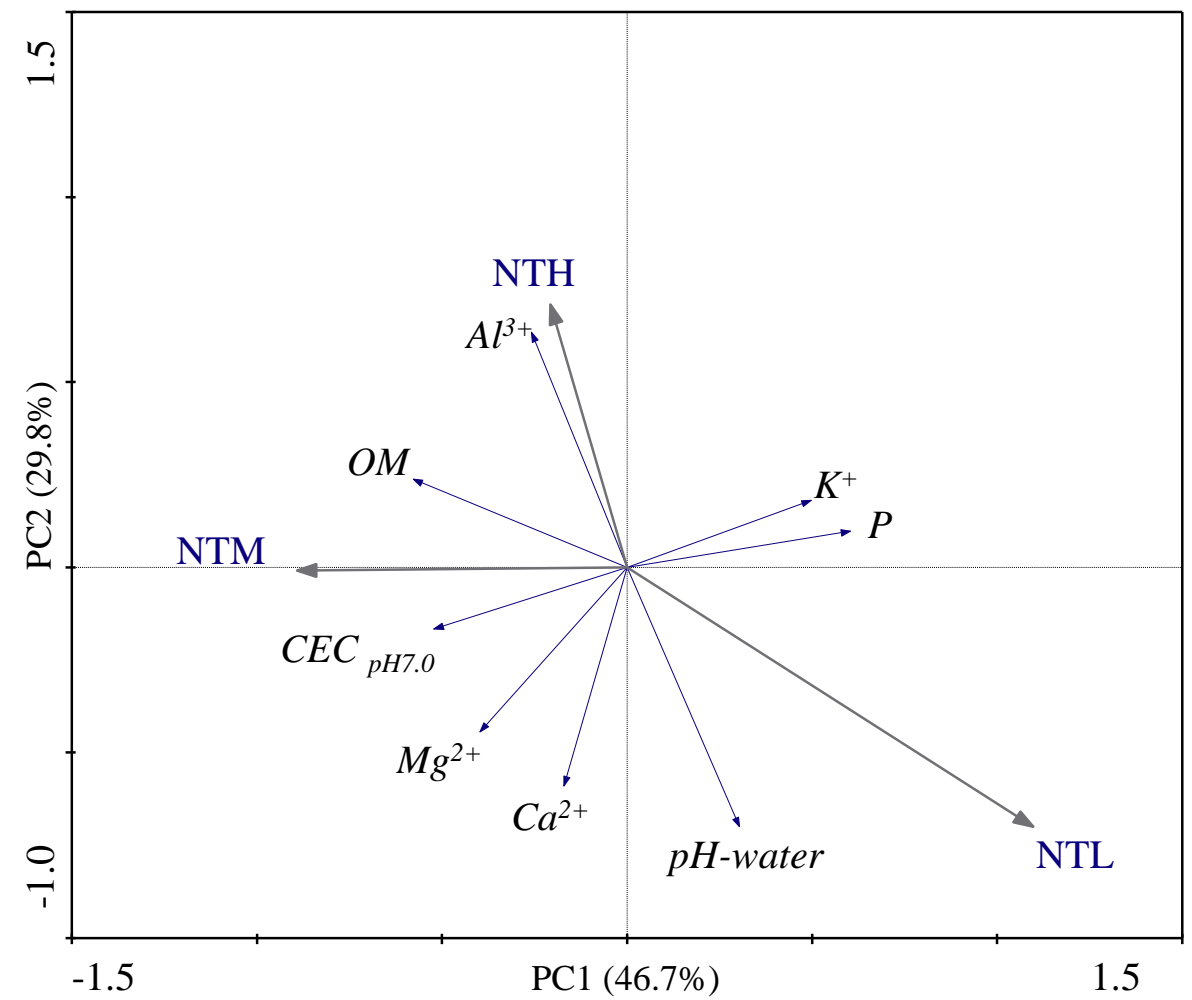

Figure 4. Principal Component Analysis (PCA) of chemical attributes evaluated in areas managed under no-tillage system of High (NTH), Medium (NTM), and Low (NTL) soybean productivity in Western Santa Catarina State, Brazil. OM = Organic Matter; $\mathrm{P}=$ Phosphorus; $\mathrm{K}^{+}=$Potassium; $\mathrm{Ca}^{2+}=$ Calcium; $\mathrm{Mg}^{2+}=$ Magnesium; $\mathrm{Al}^{3+}=$ Aluminum; pH-water; $\mathrm{CEC}_{\mathrm{pH}} 7.0=$ Cation Exchange Capacity. $\mathrm{PC} 1=$ Principal Component 1 and PC2 = Principal Component 2.

Redundancy analysis (RDA) showed a satisfactory correlation between the chemical attributes (response variable) and the physical and biological variables (explanatory environmental variables). The environmental variables explain $41 \%$ of the variability, and of this part of the variability, $56.4 \%$ is explained by axis 1 and $36.8 \%$ is explained by axis 2 (Figure 5). Thus, the use of multivariate tools proves to be important in understanding the data, so the second hypothesis is accepted. 


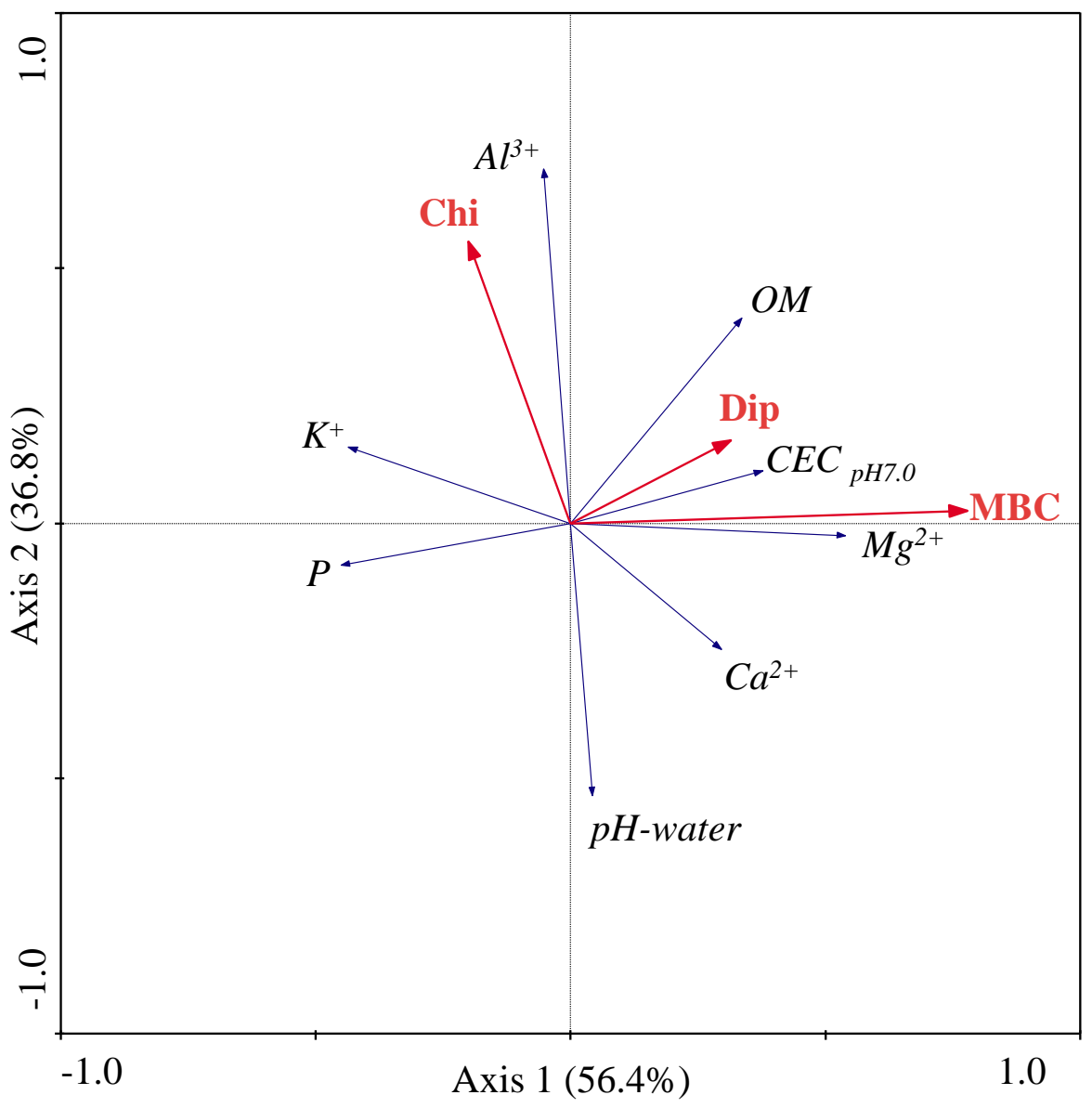

Figure 5. Redundancy Analysis (RDA) between the chemical attributes (response variable) and the physical and biological attributes (environmental explanatory variables) evaluated in areas managed under no-tillage system of High (NTH), Medium (NTM), and Low (NTL) soybean productivity in Western Santa Catarina State, Brazil. OM = Organic Matter; $\mathrm{P}=$ Phosphorus; $\mathrm{K}^{+}=$Potassium; $\mathrm{Ca}^{2+}=$ Calcium; $\mathrm{Mg}^{2+}=$ Magnesium; $\mathrm{Al}^{3+}=$ Aluminum; pH-water; $\mathrm{CEC}_{\mathrm{pH}} 7.0=$ Cation Exchange Capacity; Chi $=$ Chilopoda; $\mathrm{MBC}$ $=$ Microbial Biomass Carbon; Dip = Diplopoda.

Among the explanatory variables, it is worth mentioning that only biological variables demonstrate a significant effect on soil chemical attributes. The Diplopoda group $(p<0.05)$ affected OM content. Individuals of this group are mostly fungivores and detritivores, feeding on organic fragments with a fundamental role in the formation of soil organic matter (LEBEDEV et al., 2020), promoting the availability of nutrients to plants. The Chilopoda group showed an effect on soil aluminum content $(p<0.05)$. However, more research is needed to link the interactions of 
groups of edaphic fauna to chemical attributes such as $\mathrm{Al}^{3+}$ or its saturation in the soil, and the way they interact in the response of crops.

The MBC attribute $(p<0.01)$ showed a relationship with $\mathrm{Mg}^{2+}$ contents. This biological variable is directly related to nutrient availability (FERREIRA et al., 2017) and involves the transformation and cycling of organic matter and nutrients for plants (BALOTA et al., 2015). In this context, an important point arises, where soil biology may be affecting nutrient availability or promoting changes in the way the plant finds this nutrient in the soil since it plays an important role in soil fertility (BAGYARAJ et al., 2016). Other studies have warned of new approaches involving the availability of nutrients in NT. Like the work conducted by Moreira et al. (2016), who evaluated the availability of $\mathrm{Zn}$ and $\mathrm{Mn}$ for soybean crop under different management systems and highlighted that the high levels of nutrients in the soil, using several extractors (Mehlich I, Mehlich III, $\mathrm{HCl}$, and DTPA) were not adequate to the contents found in NT plants. That is, not necessarily the quantity is the limiting factor for productivity in NT, but how plant roots can obtain them. Thus, there is a need for a holistic approach, including soil biology in fertility studies in NTs.

\section{CONCLUSIONS}

The data approach by univariate analysis did not demonstrate differences between systems, as well as an absence of significant correlations of nutrients with plant productivity. It should be highlighted again that the nutrient contents were above the critical limit. However, the use of multivariate analyses was satisfactory in the explanation of the data, separating the systems with different soybean productivities, demonstrating that the high productivity of soybean in the NTH system was not negatively affected by higher aluminum saturation, when the nutrient values are above the critical limit and the important contribution of soil organic matter in the separation of the most productive systems (NTH and NTM) from the least productive one (NTL). The use of more robust methods of data analysis also allowed identifying the influence of biological variables such as microbial biomass carbon and edaphic fauna groups (Diplopoda and Chilopoda) on soil chemical attributes. Therefore, these studies reinforce the need for joint evaluation of chemical attributes with other areas of soil science for an adequate assessment of soybean productivity in no-tillage system, seeking a holistic approach to soil fertility. The search for and use of multivariate data analysis tools can also help in understanding the attributes that determine soybean productivity. 


\section{ACKNOWLEDGEMENTS}

The authors thank the Foundation for Sustainable Agriculture (Agrisus) for funding the project (Process No. PA 1894/16 and 2519/18), Monitoring Graduate Scholarship Program (PROMOP), and Coordination for the Improvement of Higher Education Personnel (CAPES) for granting the scholarship to E. K. To the rural producers involved. D.B. thanks the National Council for Scientific and Technological Development (CNPq) for the Productivity Grant (CNPq 305939 / 2018-1). L.C. I. O. F. thanks CNPq for granting a scholarship (CNPq 155778 / 2018-8), Financial support from Research and Innovation Support Foundation of the State of Santa Catarina (FAPESC 2019TR617) is acknowledged.

\section{REFERENCES}

ALEF, K.; NANNIPIERI, P. 1995. (Eds.) Methods in applied soil microbiology and biochemistry. London: Academic Press, 576 p.

ALVAREZ. V. H. 1996. Correlação e calibração de métodos de análise de solos. In: ALVAREZ V. H.; FONTES, L. E. F.; FONTES, M. P. F. (Eds.) O solo nos grandes domínios morfoclimáticos do Brasil e o desenvolvimento sustentado. Sociedade Brasileira de Ciência do Solo, Viçosa. 615-646 p.

ANDERSON, J. P. E.; DOMSCH, K. H. 1993. The metabolic quotient $\left(q \mathrm{CO}_{2}\right)$ as a specific activity parameter to assess the effects of environmental condition, such as $\mathrm{pH}$, on the microbial biomass of forest soils. Soil Biology and Biochemistry, v.25, p.393-395. Doi: https://doi.org/10.1016/0038-0717(93)90140-7

ANDERSON J. D.; INGRAM J. S. I. 1993. Tropical soil biology and fertility: a handbook of methods. 2 ed. Wallingford, UK CAB International. 171p.

ASHER, C. J.; OZANNE, P. G. 1961. The cation exchange capacity of plant roots, and its relationship to the uptake of insoluble nutrients. Australian Journal of Agricultural Research, v.12, p.755-766.

BALOTA, E. L.; YADA, I. F. U.; AMARAL, H. F.; NAKATANI, A. S.; HUNGRIA, M.; DICK, R. P.; COYNE, M. S. 2015. Soil quality in relation to forest conversion to perennial or annual cropping in southern Brazil. Revista Brasileira de Ciência do Solo, v.39, p.1003-1014. Doi: https://doi.org/10.1590/01000683rbcs20140675

BARETTA, D.; BARTZ, M. L. C.; FACHINI, I. A.; ANSELMI, R.; ZORTÉA, T.; MALUCHEBARETTA, C. R. D. 2014. Soil fauna and its relation with environmental variables in soil management systems. Revista Ciência Agronômica, v.45, p.871-879. Doi: https://doi.org/10.1590/S1806-66902014000500002

BEDANO, J. C.; DOMÍNGUEZ, A.; AROLFO, R.; WALL, L. G. 2016. Effect of Good Agricultural Practices under no-till on litter and soil invertebrates in areas with different soil types. Soil $\&$ Tillage Research, v.158, p.100-109. Doi: https://doi.org/10.1016/j.still.2015.12.005

BELINATO, L. D. C.; KRAFT. E.; SOLIVO, R.; OLIVEIRA, P. A.; SPAGNOLlO, E.; BARETTA, D.; MALUCHE-BARETTA, C. R. D. 2020. Multivariate tools for evaluating the 
use of organic fertilizers on soil microbial properties and maize yield. Journal of Agricultural Studies, v.8, n.3, p.257-279. Doi: https://doi.org/10.5296/jas.v8i3.16073

BLANCO-CANQUI, H.; RUIS, S. J. 2018. No-tillage and soil physical environment. Geoderma, v.326, p.164-200. Doi: https://doi.org/10.1016/j.geoderma.2018.03.011

BAGYARAJ, D. J.; NETHRAVATHI, C. J.; NITIN, K. S. 2016. Soil biodiversity and arthropods: Role in soil fertility. In: Chakravarthy A., Sridhara S. (eds) Economic and Ecological Significance of Arthropods in Diversified Ecosystems. Springer, Singapore, p.1751.

CAIRES, E. F.; JORIS, H. A. W.; CHURKA, S. 2011. Long-term effects of lime and gypsum additions on no-till corn and soybean yield and soil chemical properties in southern Brazil. Soil Use and Management, v.27, p.45-53. Doi: https://doi.org/10.1111/j.1475-2743.2010.00310.x

CAIRES, E.F.; ALLEONI, L.R.F.; CAMBRI, M.A.; BARTH, G. 2005. Surface application of lime for crop grain production under a no-till system. Agronomy Journal, v.97, p.791-798. Doi: https://doi.org/10.1590/S0103-90162006000500013

CAIRES, E.F.; BARTH, G.; GARBUIO, F.J. 2006. Lime application in the establishment of a notill system for grain crop production in Southern Brazil. Soil \& Tillage Research, v.89, p.312. Doi: https://doi.org/10.1016/j.still.2005.06.006

CARVAlHO, M. A. C.; PANOSSO, A. L.; TEIXEIRA, E. E. R.; ARAÚJO, E. G.; BRANCAGLIONI, V. A.; DALLACORT, R. 2018. Multivariate approach of soil attributes on the characterization of land use in the southern Brazilian Amazon. Soil \& Tillage Research, v.184, p.207-215. Doi: https://doi.org/10.1016/j.still.2018.08.004

CQFS RS-SC - Comissão de Química e Fertilidade do Solo RS/SC. 2016. Manual de adubação e calagem para os Estados do Rio Grande do Sul e de Santa Catarina. 11.ed. Sociedade Brasileira de Ciência do Solo - Núcleo Regional Sul, Porto Alegre, 376p.

DEBICKA, M.; KOCOWICZ, A.; WEBER, J.; JAMROZ, E. 2016. Organic matter effects on phosphorus sorption in sandy soils. Archives of Agronomy and Soil Science, v.62, p.840 855. Doi: https://doi.org/10.1080/03650340.2015.1083981

EMBRAPA. 1997. Centro Nacional de Pesquisa de Solos (Rio de Janeiro, RJ). Manual de métodos de análise de solo / Centro Nacional de Pesquisa de Solos. - 2. ed. rev. atual. - Rio de Janeiro, 212p.

FAGERIA N. K. 2001. Efeito da calagem na produção de arroz, feijão, milho e soja em solo de cerrado. Pesquisa Agropecuária Brasileira, v.36, p.1419-1424. Doi: http://dx.doi.org/10.1590/S0100-204X2001001100013.

FAVARATO, L. F.; SOUZA, J. L. DE.; GALVÃO, J. C. C.; SOUZA, C. M. DE.; GUARÇONI, R. C. 2015. Atributos químicos do solo com diferentes plantas de cobertura em sistema de plantio direto orgânico. Revista Brasileira de Agropecuária Sustentável, v.5, p.19-28. Doi: http://dx.doi.org/10.21206/rbas.v5i2.312

FEBRAPDP. 2020. Federação Brasileira de Plantio Direto na Palha, Área do sistema plantio direto. Available at: <https://febrapdp.org.br/area-de-pd> Accessed on: Jul. 02, 2020.

FERREIRA, E. P. B.; STONE, L. F.; MARTIN-DIDONET, C. C. G. 2017. População e atividade microbiana do solo em sistema agroecológico de produção. Revista Ciência Agronômica, V.48, n.1, p.22-31.

FERNÁNDEZ, F. G.; BROUDER, S. M.; VOLENEE, J. J.; BEYROUTY, C. A.; HOYUM, R. 2009. Root and shoot growth, seed composition, and yield components of no-till rainfed soybean under variable potassium. Plant Soil, v.322, p.125-138. Doi: https://doi.org/10.1007/s11104-009-9900-9 
FERNANDES, M. S.; SOUZA, S. R. 2006. Absorção de nutrientes. In: Nutrição mineral de plantas (ed. M.S. Fernandes). Sociedade Brasileira de Ciência do Solo, Viçosa. 115-153p.

KRAFT, E.; OLIVEIRA-FILHO, L. C. I.; CARNEIRO, M. C.; KLAUBERG-FILHO, O.; MALUCHE-BARETTA, C. R. D.; BARETTA, D. 2021. Edaphic fauna affects soybean productivity under no-till system. Scientia Agrícola, v.78, n.2, e20190137, Doi: https://doi.org/10.1590/1678-992X-2019-0137.

LEBEDEV, Y.; GONGALSHY, K. B.; GORBUNOVA, A. Y.; ZAITSEV, A. S. 2020. Rice straw decomposition by woodlice (Isopoda, Oniscidea) and millipedes (Myriapoda, Diplopoda) in the soils of Kalmykia in a laboratory experiment. Arid Ecosystems, v. 10, n.3, v.251-254. Doi: https://doi.org/10.1134/S2079096120030026

LOPES, A. S.; GUILHERME, L. R. G. 2007. Fertilidade do solo e produtividade agrícola. In: NOVAIS, R. F.; ALVAREZ, V. V. H.; BARROS, N. F.; FONTES, R. L. F.; CANTARUTTI, R. B.; NEVES, J. C. L. - (Eds.). Sociedade Brasileira de Ciência do Solo, Viçosa. 1-64p.

MANGALASSERY, S.; MOONEY, S. J.; SPARKES, D. L.; FRASER, W. T.; SJOGERSTEN, S. 2015. Impacts of zero tillage on soil enzyme activities, microbial characteristics and organic matter functional chemistry in temperate soils. European Journal of Soil Biology, v.68, p.917. Doi: https://doi.org/10.1016/j.ejsobi.2015.03.001

MARTINAZZO, R.; SANTOS, D. R.; GATIBONI, L. C.; BRUNETTO, G.; KAMINSKI, J. 2007. Fósforo microbiano do solo sob sistema plantio direto afetado pela adição de fosfato solúvel. Revista Brasileira de Ciência do Solo, v.31, p.563-568. Doi: https://doi.org/10.1590/S010006832007000300016.

MOREIRA, S. G.; PROCHNOW, L. I.; KIEHL, J. C.; PAULETTI, V.; MARTIN-NETO, L. 2016. Chemical forms in soil and availability of manganese and zinc to soybean in soil under different tillage systems. Soil $\&$ Tillage Research, v.163, p.41-53. Doi: https://doi.org/10.1016/j.still.2016.05.007

MOTTER, P.; ALMEIDA, H. G.; VALLE, D.; MELLO, I. 2015. Plantio direto: A tecnologia que revolucionou a agricultura brasileira. Foz do Iguaçu: Parque Itaipu. 144p.

MURPHY, B. W. 2015. Impact of soil organic matter on soil properties - a review with emphasis on Australian soils. Soil Research, v.53, p.605-635. Doi: https://doi.org/10.1071/SR14246

NICOLODI, M.; GIANELLO, C. 2015. Understanding soil as an open system and fertility as an emergent property of the soil system. Sustainable Agriculture Research, v.4, n.1, p.94 - 105. Doi: https://doi.org/10.5539/sar.v4n1p94

NICOLODI, M.; GIANELLO, C. 2017. Ruído na avaliação da fertilidade do solo e desafios a sua caracterização. Plantio Direto, v.158, p.10-25.

NICOLODI, M.; GIANELLO, C.; ANGHINONI, I.; MARRÉ, J.; MIELNICZUK, J. 2014. The mineralist concept to express the soil fertility perceived by plants grown under no-tillage system. International Journal of Agricultural Science Research, v.3, p.187-195.

NOLLA, A.; ANGHINONI, I. 2006. Critérios de calagem para a soja no sistema plantio direto consolidado. Revista Brasileira de Ciência do Solo, v.30, p.475-483. Doi: https://doi.org/10.1590/S0100-06832006000300009.

PAVINATO, P. S.; ROSOLEM, C. A. 2008. Disponibilidade de nutrientes no solo - decomposição e liberação de compostos orgânicos de resíduos vegetais. Revista Brasileira de Ciência do Solo, v.32, p.911-920. Doi: https://doi.org/10.1590/S0100-06832008000300001

PEREIRA, J. O.; MELO, D.; RICHARD, G.; DEFOSSEZ, P.; SILVA, S. L.; OLIVEIRA, F. A. DE.; BATISTA, R. O.; GARCIA, A. R. G. 2018. Yield of soybean crop in function of soil 
compaction affected by tillage system on Oxisol of subtropical region. Australian Journal of Crop Science, v.12, p.227-234. https://doi.org/10.21475/ajcs.18.12.02.pne675

REICHERT, J. M.; ROSA, V. T.; VOGELMANN, E. S.; ROSA, D. P.; REINERT, D. J.; SATTLER, A.; DENARDIN, J. E. 2016. Conceptual framework for capacity and intensity physical soil properties affected by short and long-term (14 years) continuous no-tillage and controlled traffic. Soil \& Tillage Research, v.158, p.123-136. Doi: https://doi.org/10.1016/j.still.2015.11.010

RHEINHEIMER, D. S; ANGHINONI, I. 2003. Accumulation of soil organic phosphorus by soil tillage and cropping systems in subtropical soils. Communications in Soil Science and Plant Analysis, v.34, p.2339-2354. Doi: https://doi.org/10.1081/CSS-120024068

RHEINHEIMER, D. S.; TIECHER, T.; GONZATTO, R.; ZAFAR, M.; BRUNETTO, G. 2018. Residual effect of surface-applied lime on soil acidity properties in a longterm experiment under no-till in a Southern Brazilian sandy Ultisol. Geoderma, v.313, p.7-16. Doi: https://doi.org/10.1016/j.geoderma.2017.10.024

RODRIGHERO, M. B.; BARTH, G.; CAIRES, E. F. 2015. Aplicação superficial de calcário com diferentes teores de magnésio e granulometrias em sistema plantio direto. Revista Brasileira de Ciência do Solo, v.39, p.1723-1736. http://dx.doi.org/10.1590/01000683rbcs20150036.

RUGGIERO, M. A.; GORDON, D. P.; ORRELL, T. M.; BAILY, N.; BOURGOIN, T.; BRUSCA, R. C.; CAVALIER-SMITH, T.; GUIRY, M. D.; KIRK, P. M. 2015. A higher level classification of all living organisms. Plos One, v.10, p.1-60. Doi: https://doi.org/10.1371/journal.pone.0119248

SANTOS, D. R.; GATIBONI, L. C.; KAMINSKI, J. 2008. Fatores que afetam a disponibilidade do fósforo e o manejo da adubação fosfatada em solos sob sistema plantio direto. Ciência Rural, v.38, p.576-586. Doi: http://dx.doi.org/10.1590/S0103-84782008000200049

SCHERER, E. E. 1998. Níveis críticos de potássio para a soja em Latossolo húmico de Santa Catarina. Revista Brasileira de Ciência do Solo, v.22, p.57-62. Doi: https://doi.org/10.1590/S0100-06831998000100008

TEDESCO, M. J.; GIANELLO, C.; BISSANI, C. A.; BOHNEN, H.; VOLKWEISS, S. J. 1995. Análises de Solo, Plantas e Outros Materiais. Porto Alegre: Universidade Federal do Rio Grande do Sul, 174p. (Boletim Técnico 5).

TIECHER, T.; CALEGARI, A.L.; CANER, L.; RHEINHEIMER, D. S. 2017. Soil fertility and nutrient budget after 23-years of different soil tillage systems and winter cover crops in a subtropical Oxisol. Geoderma, v.308, p.78-85. https://doi.org/10.1016/j.geoderma.2017.08.028

VANCE, E. D.; BROOKS, P. C.; JENKINSON, D. S. 1987. An extraction method for measuring soil microbial biomass C. Soil Biology and Biochemistry, v.19, p.703-707. Doi: https://doi.org/10.1016/0038-0717(87)90052-6

VIEIRA, R. C. B. 2010. Camada diagnóstica, critérios de calagem e teores críticos de fósforo e potássio em solos sob plantio direto no Centro-Sul do Paraná. Porto Alegre: Universidade Federal do Rio Grande do Sul; 2010.

VIEIRA, R. C. B.; FONTOURA, S. M. V.; BAYER, C.; MORAES, R. P.; CARNIEL, E. 2015. Adubação fosfatada para alta produtividade de soja, milho e cereais de inverno cultivados em rotação em latossolos em plantio direto no centro-sul do Paraná. Revista Brasileira de Ciência do Solo, v.39, p.794-808. Doi: http://dx.doi.org/10.1590/01000683rbcs20140463 
WANG, Y.; LI, C.; TU, C.; HOYT, G. D.; DEFOREST, J. L.; HU, S. 2017. Long-term no-tillage and organic input management enhanced the diversity and stability of soil microbial community. Science of the Total Environment, v.609, p.341-347. Doi: https://doi.org/10.1016/j.scitotenv.2017.07.053

Received in: August, 17, 2020 Accepted in: June, 18, 2021 